\title{
Corrosion Inhibition of Mild Steel in Acidic Medium by Salvadora Persica (Miswak) - Part 1: in Sulfamic Acid
}

\author{
HESHAM T.M. ABDEL-FATAH ${ }^{1,2^{*}}$, ALIAA A. M. HASSAN ${ }^{3}$, ZAKI A. SAADI ${ }^{4}$, \\ MAISON M. SHETIFY ${ }^{3}$ and HALA E.E. EL-SEHIETY ${ }^{1}$
}

${ }^{1}$ Department of Corrosion Research, Central Chemical Laboratories, EEHC, Sabtia, Cairo, Egypt

${ }^{2}$ Department of Chemical Engineering, Higher Technological Institute, Tenth of Ramadan City, Egypt

${ }^{3}$ Faculty of Science and Arts in Al-Ardha, Jazan University, Al-Ardha, Jazan, Saudi Arabia ${ }^{4}$ Department of Chemistry Laboratory, Psychiatric Hospital, Jazan, Saudi Arabia hesham_tm@yahoo.com

Received 23 July 2013 / Accepted 30 August 2013

\begin{abstract}
Aqueous root extract of Salvadora persica (ARESP) was studied as a new green corrosion inhibitor for mild steel (MS) in $1.0 \mathrm{~N}$ sulfamic acid solutions by using mass loss and electrochemical techniques at temperatures ranging from 303 to $333 \mathrm{~K}$. Appropriate equivalent circuit model was used to calculate the impedance parameters. The electrochemical impedance spectroscopy (EIS) measurements showed that the charge transfer resistance increases with an increase in the concentration of ARESP. The results obtained from the new technique electrochemical frequency modulation (EFM) indicated that ARESP acts as mixed type of inhibitor. The protection efficiency increases with the increase in inhibitor concentration and decreases with temperature. The results of the study revealed that ARESP inhibits the corrosion of MS through adsorption process following Temkin adsorption isotherm model. The apparent activation energy $\left(E_{a}\right)$ and the equilibrium constant of adsorption $\left(K_{a d s}\right)$ were calculated. Scanning electron microscopy (SEM) was used to investigate the adsorbed film of ARESP on the steel surface.
\end{abstract}

Keywords: Acid cleaning, Sulfamic acid, Corrosion inhibition, Mass loss, EIS, EFM

\section{Introduction}

Acid solutions are widely used in different industries for pickling, acid cleaning of boilers, descaling and oil well acidizing. Several acids will effectively remove waterside deposits for example, hydrochloric, sulfuric, sulfamic and citric acids are employed for such purpose ${ }^{1,2}$.

Sulfamic acid $\left(\mathrm{HSO}_{3} \mathrm{NH}_{2}\right)$ is widely used in various industrial acid cleaning applications. However, little work has been reported on the corrosion behaviour of different metal materials in sulfamic acid solutions. 
Sulfamic acid has many advantages ${ }^{1,2}$ such as:

- It is a crystalline solid, highly stable; therefore it can be easily stored and handled.

- It is a strong acid in aqueous solution with remarkable effectiveness for dissolving iron oxides and variety of water- formed scales.

- It is compatible with alloy steels and austenitic stainless steels.

Acid cleaning process requires careful monitoring to protect metals and alloys against corrosion. The uses of corrosion inhibitors are the effective and economic corrosion control method $^{3,4}$.

Increasing concern about the toxicity of most corrosion inhibitors has resulted in an increased search for green corrosion inhibitors. Several studies have been carried out on the inhibition of corrosion of metals by plant extract ${ }^{5-11}$.

Salvadora persica (Arak tree) is traditionally used for the treatment of oral infections and the young roots, stems and branches are used as toothbrush ${ }^{12-14}$. The Salvadora persica is the most common source of chewing sticks which is used in Africa, South America, Asia and the Middle East. It has different names in different societies, for instance, miswak, siwak, or arak. Pharmacological studies indicated that Salvadora persica plant has a number of proven medicinal applications and almost all parts (leaves, root bark, fruits and seeds) have been found to be medical activities ${ }^{13-16}$. On the other hand, the chemical constituents of Salvadora persica were reported earlier ${ }^{17-20}$.

There is no published research related to the corrosion inhibitive properties of Salvadora persica. Therefore, the present study aims to fill this gap and investigates the inhibitive properties of aqueous root extract of Salvadora persica (ARESP) on the corrosion behaviour of mild steel (MS) in $1.0 \mathrm{~N}$ sulfamic acid solution. Moreover, this article is a continuation of a series of publications dedicated to exploration of eco-friendly corrosion inhibitors $^{21}$. Furthermore, this study will be the first attempt of a series of research that will be addressed later for the different parts of Arak plant (Salvadora persica) as a corrosion inhibitor for a range of metals and alloys in various media.

\section{Experimental}

The roots of Arak tree (Salvadora persica) were collected from Jazan, Saudi Arabia. The dried roots $(10 \mathrm{~g})$ were cut into small pieces and were soaked in ultra-pure water $(500 \mathrm{~mL})$ and refluxed for $5 \mathrm{~h}$. The refluxed solution was filtered to remove any contamination and the aqueous solution was concentrated to $100 \mathrm{~mL}$. This extract (concentrated solution) was used to prepare solutions of different concentrations by dilution method in order to study the corrosion inhibition properties of Salvadora persica (Miswak).

\section{Material preparation}

The specimens used for corrosion tests were mild steel (MS) coupons having the following composition (wt \%): $0.07 \mathrm{C}, 0.29 \mathrm{Si}, 0.56 \mathrm{Mn}$ and the rest being Fe (99.08\%). Prior to all measurements, the steel electrodes were mechanically abraded with emery papers from 600 to 1200 grades, degreased with acetone in an ultrasonic bath, then rinsed with ultra-pure water and finally dried by warm air before use.

\section{Mass loss studies}

Measurements of mass changes were performed on rectangular coupons of size $1.5 \mathrm{~cm} \mathrm{x} 1 \mathrm{~cm} \mathrm{x}$ $0.2 \mathrm{~cm}$ with total exposed area of $\left(4 \mathrm{~cm}^{2}\right)$. The mass loss was determined by weighing the cleaned samples before and after 24 hours immersion in the tested solutions at different temperatures. 


\section{Electrochemical studies}

Electrochemical measurements were conducted in a conventional three-electrode cell of capacity $150 \mathrm{~mL}$, consisting of a steel electrode embedded in epoxy resin so that the cross sectional area $1 \mathrm{~cm}^{2}$ is only exposed to the solution, as working electrode, while a saturated calomel electrode (SCE) and a platinum electrode were used as reference and counter electrode, respectively.

The electrode was held in the test solution for 30 minutes which provided sufficient time for $E_{\text {corr }}$ to attain a reliable stable state in the open circuit potential $\left(E_{\text {ocp }}\right)$. Electrochemical impedance spectroscopy (EIS) measurements were made at corrosion potential $\left(E_{\text {corr }}\right)$ over the frequency range from 100,000 to $1 \mathrm{~Hz}$ at an amplitude of $10 \mathrm{mV}$ and scan rate of 10 points per decade.

Electrochemical frequency modulation (EFM) is a recent technique provides a new tool for electrochemical corrosion monitoring in which two sinusoidal potential signals are summed and applied to a corrosion sample through a potentiostat. The resulted current is measured and the time-domain data is converted to the frequency domain. This frequency domain is used to measure the signal at the applied fundamental frequencies, at harmonics of the fundamental frequencies, and at intermodulation frequencies. By the appropriate mathematical manipulation, the large peaks are used to directly determine the values of corrosion current density $\left(I_{\text {corr }}\right)$, corrosion rate, Tafel constants $\left(\beta_{c}\right.$ and $\left.\beta_{a}\right)$ and the causality factors (CF2 \& CF3).

EFM technique has many advantaged features such as the test requires only 2-10 min and it is considered as a non-destructive technique. The great strength of the EFM is the two causality factor (CF2 and CF3). The causality factor is calculated from the frequency spectrum of the current response. The idea behind this causality factor is that it can be used to check the validity of the EFM measurements. If the causality factors differ significantly from the theoretical values of 2 and 3, it can be deduced that the measurements are influenced by noise. If the causality factors are approximately equal to the predicted values of 2 and 3, there is a causal relationship between the perturbation signal and the response signal. Then the data are assumed to be reliable. The features and theory of EFM technique were reported previously ${ }^{27}$. The EFM measurements are performed with applying potential perturbation signal with amplitude of $10 \mathrm{mV}$ with two sine waves of 2 and $5 \mathrm{~Hz}$ and the base frequency was $1 \mathrm{~Hz}$, so the waveform repeats after $1 \mathrm{~s}$.

All Electrochemical experiments were carried out using Gamry PCI300/4 Potentiostat/ Galvanostat/Zra analyzer, EIS300 electrochemical impedance spectroscopy software, EFM140 electrochemical frequency modulation software and Echem Analyst 5.21 for results plotting, graphing, data fitting \& calculating.

\section{Results and Discussion}

\section{Mass loss results}

The mass losses of MS in static $1.0 \mathrm{~N}$ sulfamic acid solutions devoid of and containing $500 \mathrm{ppm}$ of ARESP at different temperatures were determined for $24 \mathrm{~h}$. The corrosion rate in units of millimeters per year (mm/year) can be represented by the following equation ${ }^{23}$ :

$$
\text { Corrosion rate }(\mathrm{mm} / \text { year })=3.16 \times\left(\frac{W}{D A t}\right)
$$

Where $W$ is the weight loss in milligrams, $D$ is the density in $\mathrm{g} / \mathrm{cm}^{3}(D=7.88), A$ is the area in square inches $(A=0.62)$ and $\mathrm{t}$ is the time of exposure in hours $(\mathrm{t}=24)$. 
The mass loss (mg) and corrosion rate (mm/year) for MS in $1.0 \mathrm{~N}$ sulfamic acid solutions in the absence and presence of ARESP at different temperatures are given in Table 1. The protection efficiency (PE \%) of ARESP was calculated under different experimental conditions by using the following equation:

$$
\mathrm{PE} \%=\frac{C R^{o}-C R}{C R^{o}} \times 100
$$

Where $\mathrm{CR}^{\circ}$ and $\mathrm{CR}$ are the corrosion rate obtained from mass loss measurements in the absence and presence of inhibitor, respectively. The calculated values of protection efficiency (PE \%) were also listed in Table 1.

Table 1. Mass loss results for MS in $1 \mathrm{~N}$ sulfamic acid in the absence and presence of 500 ppm of ARESP at different temperatures

\begin{tabular}{ccccc}
\hline Temp K & Conc. ppm & Mass Loss mg & Corrosion Rate mm/year & IE\% \\
\hline 303 & 0 & 139.6 & 16.19 & 0.00 \\
& 500 & 21.46 & 2.49 & 84.63 \\
313 & 0 & 186.4 & 21.62 & 0.00 \\
& 500 & 33.67 & 3.91 & 81.94 \\
323 & 0 & 248.2 & 28.79 & 0.00 \\
& 500 & 82.74 & 9.60 & 66.66 \\
333 & 0 & 324.1 & 37.59 & 0.00 \\
& 500 & 116.7 & 13.54 & 63.99 \\
\hline
\end{tabular}

The mass loss and therefore the rate of corrosion are enhanced with increasing the solution temperature but decreased with presence of ARESP. The protection efficiency (PE $\%$ ) increases in presence of ARESP as a result of increasing surface coverage by inhibitor species. However, at a given inhibitor concentration, the PE \% of ARESP decreases with rising the temperature. This behaviour is due to the decrease in the strength of adsorption process by increasing temperature, suggesting that physical adsorption may be the type of adsorption of the inhibitor on the sample surfaces ${ }^{24}$.

\section{Electrochemical impedance spectroscopy results}

Figure 1 illustrates the Nyquist diagrams for MS in static $1.0 \mathrm{~N}$ sulfamic acid solutions in the absence and presence of different concentrations of ARESP at $323 \mathrm{~K}$ as an example. The impedance spectra exhibit one single capacitive loop, which indicates that the corrosion of steel is mainly controlled by a charge transfer process ${ }^{25}$.

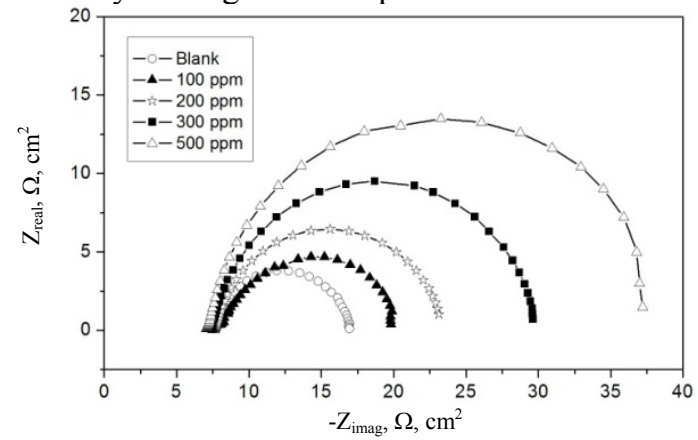

Figure 1. Nyquist diagrams of MS in $1 \mathrm{~N}$ sulfamic acid in the absence and presence of different concentrations of ARESP at $323 \mathrm{~K}$ 
The EIS results were interpreted in terms of an equivalent circuit, which is shown in Figure 2. In this figure, a Constant-Phase Element (CPE) was introduced instead of pure capacitance because the semicircles of the Nyquist plots are depressed, which can be attributed to the frequency dispersion due to the roughness and inhomogeneous of electrode surface ${ }^{26}$. The EIS parameters such as charge transfer resistance $\left(R_{c t}\right)$ and the double layer capacitance $\left(C_{d l}\right)$ of ARESP at different temperatures are given in Table 2.

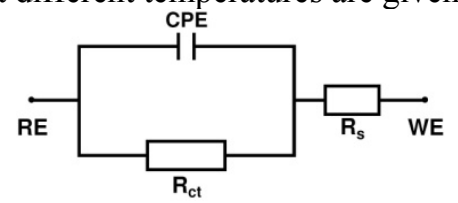

Figure 2. Electrical equivalent circuit representing the fitting of EIS data

Table 2. EIS results for MS in $1 \mathrm{~N}$ sulfamic acid with various concentrations of ARESP at different temperatures

\begin{tabular}{ccccc}
\hline Temp., $\mathrm{K}$ & Conc., $\mathrm{ppm}$ & $C_{d l} \mu \mathrm{F} . \mathrm{cm}^{-2}$ & $R_{c t}$ ohm.cm & PE, $\%$ \\
\hline 303 & 0 & 1234 & 15.58 & 0.00 \\
& 100 & 876.5 & 22.17 & 29.72 \\
& 200 & 591.4 & 32.89 & 52.63 \\
& 300 & 347.3 & 53.93 & 71.11 \\
313 & 500 & 162.4 & 109.61 & 85.79 \\
& 0 & 1618 & 11.88 & 0.00 \\
& 100 & 1228 & 15.93 & 25.42 \\
& 200 & 845.6 & 22.34 & 46.82 \\
323 & 300 & 583.7 & 33.11 & 64.12 \\
& 500 & 396.0 & 53.63 & 77.85 \\
& 0 & 2389 & 8.53 & 0.00 \\
& 100 & 1881 & 10.64 & 19.83 \\
333 & 200 & 1511 & 14.27 & 40.22 \\
& 300 & 974.8 & 20.86 & 59.11 \\
& 500 & 689.3 & 29.95 & 71.52 \\
& 0 & 2879 & 7.11 & 0.00 \\
& 100 & 2432 & 8.14 & 12.65 \\
& 200 & 1988 & 10.47 & 32.09 \\
& 300 & 1354 & 14.61 & 51.33 \\
& 500 & 999.1 & 20.09 & 64.61 \\
\hline
\end{tabular}

Inspections of the obtained data listed in Table 2 indicate that the values of charge transfer resistance $\left(R_{c t}\right)$ increase, while the double layer capacitance $\left(C_{d l}\right)$ decreases as the concentration of ARESP increases from $100 \mathrm{ppm}$ to $500 \mathrm{ppm}$. This is attributed to an increase in the surface coverage by the inhibitor molecules leading to an increase in the thickness of the electrical double layer which is responsible for the decrease in $C_{d l}$ values. This suggests that ARESP acts by adsorbed at the metal/solution interface by the gradual replacement of water molecules and the resulted adsorption film isolates the metal surface from the corrosive medium. The above conclusions can be explained on the basis that the electrostatic adsorption of the inhibitor species at the metal surface leads to the formation of a physical protective film that retards the charge transfer process and therefore inhibits the corrosion reactions and so increases the value of $\left(R_{c t}\right)$. Moreover, the adsorbed inhibitor species decrease the electrical capacity of the electrical double layer at the electrode/solution interface and therefore decrease the values of $\left(C_{d l}\right)^{27,28}$. 
Because the reciprocal of charge transfer resistance $\left(1 / \mathrm{R}_{\mathrm{ct}}\right)$ is directly proportional to the rate of corrosion, the values of the protection efficiency (PE \%) were calculated by comparing the values of the charge transfer resistance in the absence $\left(R_{c t}^{o}\right)$ and presence $\left(R_{c t}\right)$ of inhibitor by use of the relationship:

$$
\mathrm{PE} \%=\frac{R_{c t}-R_{c t}^{o}}{R_{c t}} \times 100
$$

The values of PE \% of ARESP at different temperatures were listed in Table 2; these clearly show that the protection efficiency by ARESP depends on both the concentration of the inhibitor and temperature: PE \% of ARESP increases with increasing inhibitor concentration and decreases with increasing temperature which suggests weakening of physical adsorption of ARESP.

\section{Electrochemical frequency modulation (EFM) results}

Figure 3 shows the plots of the current as a function of frequency that were obtained by EFM for MS in static $1.0 \mathrm{~N}$ sulfamic acid solutions devoid of and containing $500 \mathrm{ppm}$ of ARESP at $313 \mathrm{~K}$. The EFM data, including corrosion current density $\left(I_{\text {corr }}\right)$, Tafel constants $\left(\beta_{c}\right.$ and $\left.\beta_{a}\right)$ and the causality factors (CF2 and CF3) are given in Table 3.

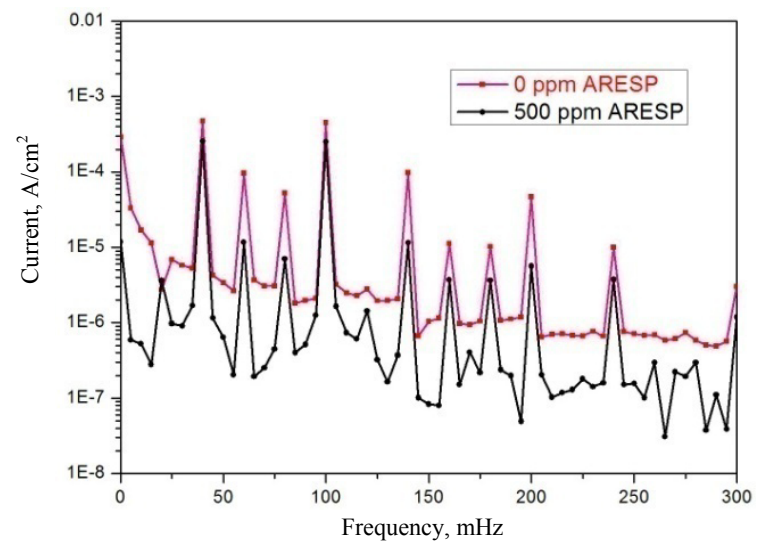

Figure 3. Intermodulation spectra of MS in $1 \mathrm{~N}$ sulfamic acid devoid of and containing $500 \mathrm{ppm}$ of ARESP at $313 \mathrm{~K}$

It is obvious from Table 3 that, the corrosion current density $\left(I_{\text {corr }}\right)$ and hence the corrosion rate decreases in presence of ARESP, which suggests that the rate of electrochemical reaction is reduced due to the formation of a barrier layer over the steel surface by the inhibitor. Moreover, the values of $I_{\text {corr }}$ are directly proportional to temperature as a result of partial de-sorption of inhibitor species from the metal surface. The values of $\beta_{c}$ and $\beta_{a}$ do not show any appreciable change indicating that the studied inhibitor is mixed type inhibitor ${ }^{29}$. Additionally, the causality factors CF2 and CF3 are very close to the theoretical values 2.0 and 3.0, respectively, indicating that the measured data are validated ${ }^{22}$.

Because corrosion rate is directly related to corrosion current density $\left(I_{\text {corr }}\right)$, the protection efficiency (PE \%) at different inhibitor concentrations and temperatures can be calculated by using the following equation:

$$
\mathrm{PE} \%=\frac{I_{\text {corr }}^{o}-I_{\text {corr }}}{I_{\text {corr }}^{o}} \times 100
$$


Table 3. EFM results for MS in $1 \mathrm{~N}$ sulfamic acid with various concentrations of ARESP at different temperatures

\begin{tabular}{cccccccc}
\hline $\begin{array}{c}\text { Temp. } \\
\mathrm{K}\end{array}$ & $\begin{array}{c}\text { Conc. } \\
\mathrm{ppm}\end{array}$ & $\begin{array}{c}\beta_{a} \\
\mathrm{mV} . \mathrm{dec}^{-1}\end{array}$ & $\begin{array}{c}\beta_{c} \\
\mathrm{mV} . \mathrm{dec}^{-1}\end{array}$ & $\mathrm{CF} 2$ & $\mathrm{CF} 3$ & $\begin{array}{c}I_{\text {corr }} \\
\mu \mathrm{A} . \mathrm{cm}^{-2}\end{array}$ & $\mathrm{PE} \%$ \\
\hline 303 & 0 & 63.18 & 185.47 & 2.101 & 3.227 & 1193.00 & 0.00 \\
& 100 & 62.61 & 186.81 & 1.914 & 3.269 & 814.74 & 31.71 \\
& 200 & 62.92 & 184.64 & 2.275 & 2.891 & 562.49 & 52.85 \\
& 300 & 64.27 & 187.11 & 1.965 & 3.204 & 351.11 & 70.57 \\
313 & 500 & 65.54 & 184.38 & 1.910 & 3.152 & 187.87 & 84.25 \\
& 0 & 64.57 & 188.58 & 1.894 & 2.938 & 1808.00 & 0.00 \\
& 100 & 65.18 & 187.66 & 2.255 & 2.846 & 1314.00 & 27.32 \\
& 200 & 64.37 & 189.13 & 1.797 & 2.677 & 954.00 & 47.23 \\
323 & 500 & 65.27 & 187.89 & 2.084 & 3.054 & 594.00 & 67.15 \\
& 000 & 65.62 & 188.35 & 1.945 & 3.187 & 376.30 & 79.19 \\
& 100 & 65.34 & 186.78 & 1.919 & 2.974 & 2364.00 & 0.00 \\
& 200 & 64.58 & 187.68 & 2.208 & 3.171 & 1847.00 & 21.87 \\
& 300 & 65.92 & 188.18 & 1.932 & 3.114 & 1467.00 & 37.94 \\
333 & 500 & 66.17 & 188.53 & 1.867 & 2.751 & 1079.00 & 54.36 \\
& 0 & 66.82 & 187.66 & 1.851 & 2.976 & 3157.00 & 0.00 \\
& 100 & 65.78 & 190.67 & 1.994 & 3.158 & 2778.00 & 12.01 \\
& 200 & 64.29 & 191.38 & 2.354 & 2.857 & 2260.00 & 28.41 \\
& 300 & 64.08 & 188.74 & 2.203 & 3.234 & 1645.00 & 47.89 \\
& 500 & 65.96 & 192.84 & 2.091 & 2.884 & 1201.00 & 61.96 \\
\hline
\end{tabular}

Where $I_{\text {corr }}^{0}$ and $I_{\text {corr }}$ represent corrosion current density values without and with inhibitor, respectively. The results of PE \% are included in Table 3. It is clear that the protection efficiency of ARESP increases with increasing inhibitor concentration, and decreases with increasing solution temperature.

It is worth mentioned that the results obtained from the different techniques used in this work (mass loss, EIS, and EFM) are in good agreement and follow almost the same trends. Therefore, EFM seems to be a promising new technique for monitoring corrosion inhibition.

\section{Apparent activation energy calculation}

The activation energy $\left(E_{a}\right)$ for inhibition by ARESP in $1.0 \mathrm{~N}$ sulfamic acid solution was calculated using the following Arrhenius equation:

$$
\log \mathrm{CR}=\frac{-E_{a}}{2.303 R T}+A
$$

Where $\mathrm{CR}$ is the rate of corrosion, $E_{a}$ is the apparent activation energy, $R$ is the universal gas constant, $T$ is the absolute temperature, and $A$ is the Arrhenius pre-exponential factor.

Figure 4 shows the plots of logarithm of $I_{\text {corr }}$ obtained from the EFM technique versus $1 / T$ give straight lines with slopes equal to $\left(-E_{a} / 2.303 \mathrm{R}\right)$. The apparent activation energy $\left(E_{a}\right)$ of various concentrations of ARESP is given in Table 4 . Analysis of the results in Table 4 reveals that values of $E_{a}$ increase with increasing concentration of the inhibitor, suggesting that the energy barrier of the corrosion reaction is increased by increasing the concentration of inhibitor. It is also observed that the apparent activation energy is higher in the presence 
of inhibitor than in its absence. Additionally, it is clear that ARESP retards corrosion at ordinary temperatures much more than at elevated temperatures and, therefore, the type of adsorption of ARESP on MS surface in $1.0 \mathrm{~N}$ sulfamic acid solutions is physical adsorption $^{30-32}$.

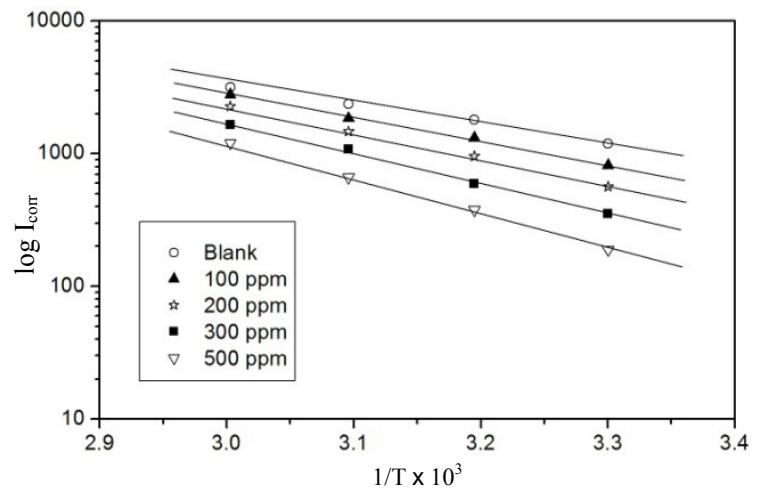

Figure 4. Arrhenius plots of MS in $1 \mathrm{~N}$ sulfamic acid in the absence and presence of various concentrations of ARESP

Table 4. Apparent activation energy of various concentrations of ARESP using the obtained data from EFM technique

\section{Adsorption isotherm}

\begin{tabular}{cc}
\hline Conc., $\mathrm{ppm}$ & $\mathrm{Ea}, \mathrm{kJ} / \mathrm{mol}$ \\
\hline 0 & 30.16 \\
100 & 34.62 \\
200 & 39.93 \\
300 & 45.57 \\
500 & 53.09 \\
\hline
\end{tabular}

The adsorption isotherm can provide valuable information about the nature of the interactions of inhibitor species with the metal surface. In general, there are two main types of adsorption interaction: physical adsorption and chemisorption, which are affected by the nature and the charge of the metal, the chemical structure of the inhibitor, and the type of electrolyte.

The degree of surface coverage $(\theta=\mathrm{PE} \% / 100)$ for different concentrations of ARESP on MS surface in static $1.0 \mathrm{~N}$ sulfamic acid was estimated for different temperatures. Figure 5 shows the plots of the degree of surface coverage $(\theta)$ that were obtained by EIS results versus the logarithm of inhibitor concentration $\left(\mathrm{C}_{\mathrm{inh}}\right)$ yield straight lines, proving that adsorption of ARESP on the MS surface obeys the Temkin adsorption isotherm ${ }^{33}$.

From the intercepts and slopes of these straight lines of Temkin isotherm curves, values of equilibrium constant $\left(K_{a d s}\right)$ were calculated and given in Table 5. Inspection of the data listed in Table 5 reveals that the values of $K_{a d s}$ are relatively small, confirming the suggestion that ARESP is physically adsorbed on the metal surface ${ }^{34}$. It is also apparent that values of $K_{a d s}$ decrease with increasing temperature. This confirms the suggestion that the strength of adsorption decreases with increasing temperature and hence the inhibitor species are more easily removed from the steel surface by the solvent solutions $s^{24,34,35}$. 


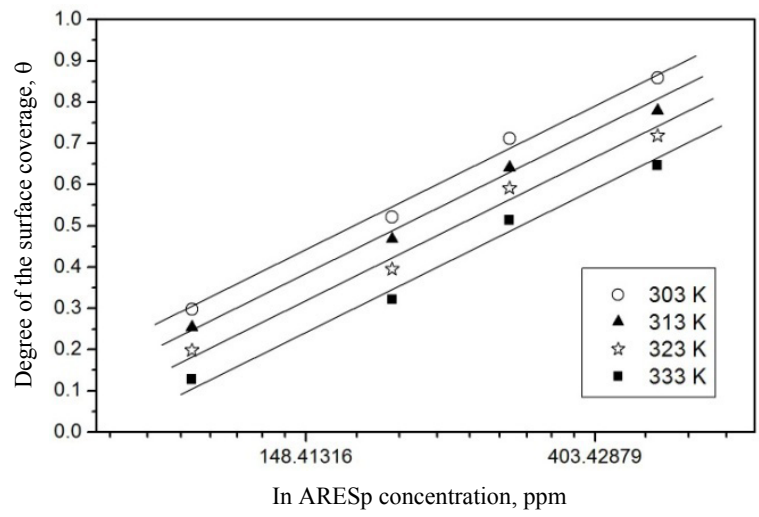

Figure 5. Temkin isotherm plots of MS in $1 \mathrm{~N}$ sulfamic acid in the presence of different concentrations of ARESP at different temperatures (data obtained from EIS technique)

Table 5. Equilibrium constant of adsorption for ARESP at different temperatures using the obtained data from EIS technique

\begin{tabular}{lc}
\hline Temp. K & $K_{a d s}$ \\
\hline 303 & 357.63 \\
313 & 281.51 \\
323 & 239.78 \\
333 & 206.47 \\
\hline
\end{tabular}

\section{Examination of surface morphology}

Formation of protective films of the inhibitor molecules on the electrode surface was further confirmed by scanning electron microscope (SEM). Figure 6 shows the SEM photos of MS samples after immersion for 24 hours in static $1.0 \mathrm{~N}$ sulfamic acid solutions, in the absence and presence of $500 \mathrm{ppm}$ of ARESP at $303 \mathrm{~K}$.

Figure 6a reveals that the surface of MS after immersion in uninhibited sulfamic acid solution, appears an aggressive attack of the corroding medium on the steel surface. Moreover, the surface layer is rather rough.

In contrast, Figure $6 \mathrm{~b}$ clearly shows that there is an adsorbed film on MS surface in inhibited sulfamic acid. The protective nature of this film reflects the values of protection efficiency obtained from the chemical and electrochemical methods, which suggests that ARESP is good inhibitor for the corrosion of mild steel in sulfamic acid solutions.
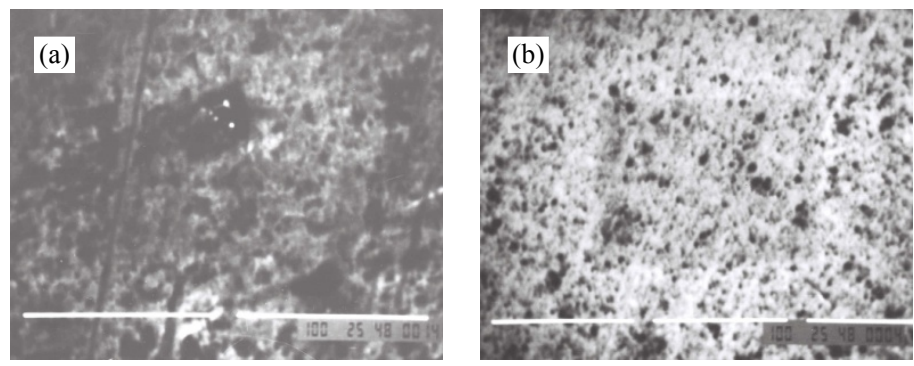

Figure 6. SEM micrographs of MS surface after immersion for 24 hours in $1 \mathrm{~N}$ sulfamic acid; (a) in the absence and (b) presence of 500 ppm of ARESP at $303 \mathrm{~K}$ 


\section{Conclusion}

The inhibition of mild steel corrosion in sulfamic acid solution by ARESP has been studied by mass-loss study and electrochemical measurements along with microscopy examinations. The MS corrosion can be inhibited evidently by the aqueous root extract of Salvadora persica (ARESP). EIS spectra reveal that a protective film is formed on the metal surface. EFM study reveals that ARESP functions as a mixed inhibitor. The adsorption of ARESP on mild steel follows the Temkin adsorption isotherm. All of the chemical and electrochemical data are in good agreement with the morphology characteristic, showing that ARESP is a good inhibitor by forming a monolayer on the steel surface.

\section{References}

1. Majnouni M D and Arif E Jaffer, Chemical Cleaning of an Industrial Boiler-An Overview. International Water Conference paper no. IWC-03-34, 2003, 1.

2. McCoy J W, Industrial Chemical Cleaning, Chemical Publishing Co., ISBN:0-82060305-8, New York, 1984.

3. Sathiyanarayanan S, Jeyaprabha C, Muralidharan S and Venkatachari G, Appl Surf Sci., 2006, 252(23), 8107-8112; DOI:10.1016/j.apsusc.2005.10.028

4. Ashassi-Sorkhabi $\mathrm{H}$ and Asghari E, Electrochim Acta, 2008, 54(2), 162-167; DOI:10.1016/j.electacta.2008.08.024.

5. Okafor P C, Ikpi M E, Uwah I E, Ebenso E E, Ekpe U J and Umoren S A, Corros Sci., 2008, 50(8), 2310-2317; DOI:10.1016/j.corsci.2008.05.009

6. Rajendran S, Ganga Sri V, Arockiaselvi J and Amalraj A J, Bulletin of Electrochem., 2005, 21, 367.

7. Sethuraman M G and Raja P B, Pigment Resin Technol., 2005, 34(6), 327-331; DOI:10.1108/03699420510630345

8. Olusegun K, Abiola J O E and Otaigbe O J Kio, Corros Sci., 2009, 51(8), 1879-1881; DOI:10.1016/j.corsci.2009.04.016.

9. Hazwan Hussin M and Jain Kassim M, Mater Chem Phys., 2011, 125(3), 461-468; DOI:10.1016/j.matchemphys.2010.10.032

10. $\quad$ El-Etre A Y, Mater Chem Phys., 2011, 108(2-3), 278-282;

DOI:10.1016/j.matchemphys.2007.09.037.

11. Shuduan Deng and Xianghong Li, Corros Sci., 2012, 55, 407-415; DOI:10.1016/j.corsci.2011.11.005.

12. Al-Otaibi, M, Al-Harthy M, Gustafsson A, Johansson A, Cleasson R and AngmarMansson B, J Clin Periodontol., 2004, 31(12), 1048-1053;

DOI:10.1111/j.1600-051X.2004.00618.x

13. Almas K, J Contemp Dent Prac., 2002, 3(3), 27-35.

14. Darmani H, Nusayr T and AL-Hiyasat A S, Int Dent Hyg., 2006, 4(2), 62-66; DOI: $10.1111 /$ j.1601-5037.2006.00149.x

15. Almas K, Skaug N and Ahmad I, Int J Dent Hyg., 2005, 3(1), 18-24; DOI:10.1111/j.1601-5037.2004.00111.x

16. Savithramma N, Sulochana C H and Rao K N, J Ethnopharmacol., 2007, 113(1), 54-61; DOI:10.1016/j.jep.2007.04.004

17. Ezmirly S T, Cheng J C and Wilson S R, Saudi Arabian Medicinal Plants: Salvadora Persica. Planta Medica 1979, 35, 191-192; DOI:10.1055/s-0028-1097205

18. Abdel Waheb S M, Selim M A and EI-Fiki N M, Bull Fac Pharm., 1990, 28(1), 67-70. 
19. Bader Ammar, Flamini Guido, Pier Luigi Cioni and Ivano Morelli, J Essential Oil Research, 2002, 14(2), 128-129; DOI:10.1080/10412905.2002.9699795

20. Abd El Rahman Howaida F and Skaug Nils Whyatt, Pharma Bio., 2003, 41(6), 399-404.

21. Hesham T M Abdel-Fatah, Anti-Corros Methods Mater., 2012, 59(1), 23-31; DOI:10.1108/00035591211190517

22. Bosch R W, Hubrecht J, Bogaerts W F and Syrett B C, Corrosion, 2001, 57(1), 60-70.

23. Fontana M G, "Corrosion Engineering," $3^{\text {rd }}$ Edition, McGraw-Hill Book Company, New York, USA, 1987.

24. Abd El Rehim S S, Hassan H H and Amin M A, Mater Chem Phys., 2002, 78(2), 337-348; DOI:10.1016/S0254-0584(01)00602-2

25. Behpour M, Ghoreishi S M, Mohammadi N, Soltani N and Salavati-Niasari M, Corros Sci., 2010, 52(12), 4046-4057; DOI:10.1016/j.corsci.2010.08.020

26. Lebrini M, Lagrenée M, Vezin H, Traisnel M and Bentiss F, Corros Sci., 2007, 49(5), 2254-2269; DOI:10.1016/j.corsci.2006.10.029

27. Mansfield F, Corrosion Mechanism, Marcel Dekker, New York, 1987, 119.

28. McCafferty E and Hackerman N, J Electrochem Soc., 1972, 119(2), 146-154; DOI:10.1149/1.2404150

29. Abd El-Maksoud S A and Fouda A S, Mater Chem Phys., 2005, 93(1), 84-90; DOI:10.1016/j.matchemphys.2005.02.020.

30. Popova A, Sokolova E, Raicheva S and Christov M, Corros Sci., 2003, 45(1), 33-58; DOI:10.1016/S0010-938X(02)00072-0

31. E.E. Oguzie, Corros Sci., 2008, 50, 2993.

32. Jovancicevic V, Ramachandran S and Prince P, Corrosion, 1999, 55(3), 449-455.

33. Oguzie E E, Unaegbu C, Ogukwe C N, Okolue B N and Onuchukwu A I, Mater Chem Phys., 2004, 84(2-3), 363-368; DOI:10.1016/j.matchemphys.2003.11.027

34. Keera S T and Deyab M A, Colloids Surfaces A: Physicochem Eng Aspects, 2005, 266(1-3), 129-140; DOI:10.1016/j.colsurfa.2005.05.069

35. El Azhar M, Traisnel M, Mernari B, Gengembre L, Bentiss F and Lagrenee M, Appl Surf Sci., 2002, 185(3-4), 197-205; DOI:10.1016/S0169-4332(01)00650-X 